\title{
Some endocrine changes associated with the post-partum period of the suckling beef cow
}

\author{
N. C. Rawlings, L. Weir, B. Todd, J. Manns and J. H. Hyland \\ Department of Veterinary Physiological Sciences, Western College of Veterinary Medicine, \\ University of Saskatchewan, Saskatoon, Saskatchewan, S7N OW0, Canada
}

\begin{abstract}
Summary. Seven Hereford cows with single calves were bled by jugular venepuncture, daily from parturition until 63-79 days post partum; 6 of the cows were also bled through jugular cannulae every $15 \min$ for $8 \mathrm{~h}$ every 10 days. The average post-partum interval to first oestrus was $59.8 \pm 3.7$ days for 5 of the cows. In cows returning to oestrus, plasma concentrations of progesterone were low until $55.5 \pm 3.0$ days post partum, rose to exceed $0.5 \mathrm{ng} / \mathrm{ml}$ plasma for $4.0 \pm 0.4$ days, declined for $5.0 \pm 0.5$ days and then rose again to normal luteal-phase levels. First oestrus preceded the initial rise in progesterone in 1 cow and followed it in 4. Ovarian palpation revealed considerable follicular development before the initial rise in progesterone, but no clearly discernable corpus luteum until normal luteal-phase progesterone levels were detected. Plasma concentrations of oestradiol-17 $\beta$ fell after parturition and, although very variable, showed no apparent trend thereafter. Plasma concentrations of $\mathrm{LH}$ varied in an episodic manner, with an apparent increase in frequency and magnitude of peaks up to 10-33 days before the first elevation in plasma progesterone. Subsequently there was little change, except for a decline in peak LH concentrations after the initial elevation in plasma progesterone.
\end{abstract}

\section{Introduction}

Following parturition in the cow there is a significant period of anoestrus, of variable length (Morrow, Roberts \& McEntee, 1969). This period of reproductive inactivity is longer in the suckling or intensively milked animal (Morrow et al., 1969; Short, Bellows, Moody \& Howland, 1972). In the suckling beef cow post-partum anoestrus can be $<50$ days or $>90$ days (Morrow et al., 1969), and an excessively long anoestrus creates managerial problems if a calf crop per year is expected. Follicular development is apparently depressed in the post-partum cow and recovers at a variable rate, again being slowest in the suckling cow (Wagner \& Oxenreider, 1971), and ovulation can often occur initially without any external manifestations of oestrus (Saiduddin, Riesen, Tyler \& Casida, 1968). Post-partum anoestrus is not a result of the maintenance of the corpus luteum of pregnancy (Labhsetwar, Collins, Tyler \& Casida, 1964) and uterine involution, although difficult to assess, would appear to occur rapidly after parturition (Wagner \& Hansel, 1969).

The endocrinology of the post-partum anoestrus is not well understood; pituitary follicle-stimulating hormone (FSH) concentrations appear to be highest at calving and then decline (Labhsetwar et al., 1964), whereas pituitary LH concentrations tend to rise (Saiduddin et al., 1968). Arije, Wiltbank \& Hopwood (1974) investigated the temporal pattern of concentrations of several hormones in jugular plasma in post-partum suckling beef cows. Progesterone concentrations were low post partum and LH concentrations, although low 
initially, showed periodic fluctuations, culminating eventually in a preovulatory surge. Other workers have shown for dairy and beef cattle that serum concentrations of oestrogen are low after parturition (Smith, Edgerton, Hafs \& Convey, 1973; Corah, Quealy, Dunn \& Kaltenbach, 1974) and that progesterone concentrations may in fact rise before first oestrus (Pope, Gupta \& Munro, 1969; Donaldson, Bassett \& Thorburn, 1970; Lamming \& Bulman, 1976; Webb, Lamming, Haynes, Hafs \& Manns, 1977; Schams et al., 1978). Recent evidence suggests that plasma concentrations of $\mathrm{LH}$ post partum may vary in an episodic pattern with increasing frequency of elevations of $\mathrm{LH}$ concentration as first ovulation approaches (Stevenson \& Britt, 1979).

The purpose of the present study was to correlate the recovery of ovarian activity, the occurrence of first oestrus and the temporal patterns of plasma concentrations of $\mathrm{LH}$, oestradiol-17 $\beta$ and progesterone during the post-partum period in the suckling beef cow.

\section{Materials and Methods}

Seven Hereford cows, each suckling a single calf, were bled daily by jugular venepuncture for 63-79 days, starting on the day of parturition. At approximately 10-day intervals, blood samples were taken every $15 \mathrm{~min}$ for $8 \mathrm{~h}(08: 30-16: 30 \mathrm{~h})$ from 6 of the 7 cows, using indwelling jugular cannulae. Ovarian palpation per rectum was performed every 2-5 days, starting at approximately 25 days post partum. The cattle were kept at pasture during the study and were weighed every 2 weeks; the calves accompanied the cows at all times. The first occurrence of oestrus was detected by the exposure of a Kamar heat mount detector by a bull.

Assays

All blood samples were centrifuged immediately and heparinized plasma was stored at $-15^{\circ} \mathrm{C}$ until assayed. Plasma samples were analysed by established radioimmunoassays (Rawlings, Kennedy, Chang, Hill \& Henricks, 1977) for LH, progesterone and oestradiol-17 .

$L H$ was measured in a double-antibody assay, established for bovine and ovine $\mathrm{LH}$, that utilized an anti-ovine LH serum that cross-reacts with bovine LH (GDN-15; Niswender, Reichert, Midgley \& Nalbandov, 1969). Highly purified bovine LH (LER-1716-2) was iodinated by the method of Greenwood, Hunter \& Glover (1963) and NIH-LH-B7 was used as the bovine LH reference preparation. Duplicate determinations were made for all samples using $200 \mu \mathrm{l}$ plasma. The assay standard curve ran from 0.08 to $20 \mathrm{ng}$ per assay tube, giving a sensitivity of $0.40 \mathrm{ng} / \mathrm{ml}$ plasma, i.e. the lowest concentration of unlabelled LH that significantly displaced labelled LH $(P<0.05)$. The inter-assay coefficient of variation was $16 \%(n=17)$.

Progesterone was extracted from plasma with petroleum ether and the extracts were assayed directly using an antiserum specific for progesterone (HD-RC-4/10/73; Rawlings et al., 1977). Duplicate determinations were made for all samples using $200 \mu \mathrm{l}$ plasma and all determinations were corrected for procedural losses. The assay standard curve ran from 31 to $500 \mathrm{pg}$ per assay tube and assay sensitivity was thus $155 \mathrm{pg} / \mathrm{ml}$ plasma. The average extraction efficiency was $90 \pm 1.9 \%$ (s.e.m., $n=23$ ), the assay blank was $24.4 \pm 9.2 \mathrm{pg}(n=5) /$ tube and the inter-assay coefficient of variation was $8 \cdot 5 \%(n=21)$.

Oestradiol $-17 \beta$ was extracted from plasma with diethyl ether and the extracts were assayed directly using an antiserum that had a $9 \%$ cross-reaction with oestrone, but $<0.01 \%$ with oestriol, oestradiol-17 $\alpha$ and all other steroids tested (NCR-8145; Rawlings et al., 1977). Duplicate determinations were made for all samples using $1 \mathrm{ml}$ plasma and all estimations were corrected for procedural losses. The assay standard curve ran from $2.50 \mathrm{pg}$ to $40 \mathrm{pg}$ per assay tube, giving a sensitivity of $2.50 \mathrm{pg} / \mathrm{ml}$ plasma. The average extraction efficiency was $82 \pm 1.5 \%$ $(n=33)$, the assay blank was $0.6 \pm 0.33 \mathrm{pg}(n=21) /$ tube and the inter-assay coefficient of variation was $21 \cdot 5 \%(n=12)$. 


\section{Analyses}

All data summaries are expressed as means with s.e.m. Analysis of variance and Duncan's multiple range test, both modified if appropriate for unequal numbers (Steele \& Torrie, 1960) were used to examine the results statistically. To examine the apparent episodic nature of $\mathrm{LH}$ secretion, peaks in concentration of LH in plasma were defined as values greater than the mean plus twice the standard error of the mean.

\section{Results}

The average body weights for the 7 cows studied were $480 \pm 11 \mathrm{~kg}$ when weighed within 1 week before calving, $432 \pm 8 \mathrm{~kg}$ within 3 days after calving, $423 \pm 8 \mathrm{~kg}$ at 11-28 days after calving

Table 1. The number and height of peaks of LH over 10-day intervals in 6 cows returning to oestrus after parturition

\begin{tabular}{ccccccc}
\hline & $\begin{array}{c}\text { Days } \\
-50 \text { to }-40\end{array}$ & $\begin{array}{c}\text { Days } \\
-39 \text { to }-30\end{array}$ & $\begin{array}{c}\text { Days } \\
-29 \text { to }-20\end{array}$ & $\begin{array}{c}\text { Days } \\
-19 \text { to }-10\end{array}$ & $\begin{array}{c}\text { Days } \\
-9 \text { to }-10\end{array}$ & $\begin{array}{c}\text { Days } \\
1 \text { to } 10\end{array}$ \\
\hline $\begin{array}{c}\text { Peak height } \\
\text { (ng/ml) }\end{array}$ & $4.8 \pm 2.8$ & $5.9 \pm 1.55$ & $14.9 \pm 7.24$ & $7.4 \pm 1.09$ & $9.8 \pm 1.18$ & $7.9 \pm 1.15$ \\
$\begin{array}{l}\text { No. of peaks } \\
\text { N }\end{array}$ & $0.3 \pm 0.21$ & $1.0 \pm 0.37$ & $1.0 \pm 0.63$ & $3.3 \pm 0.72^{*}$ & $4.3 \pm 0.92$ & $3.5 \pm 0.67$ \\
\hline
\end{tabular}

Values are mean \pm s.e.m.

The data are centered around the first period when serum concentrations of progesterone exceeded $0.5 \mathrm{ng} / \mathrm{ml}$ for 3 consecutive days; Day 0 is the 2 nd day of such a period.

* Significantly different from each of the previous 3 observations.

Table 2. Structures detected by palpation per rectum in the right (R) and left (L) ovaries of suckling beef cows

\begin{tabular}{|c|c|c|c|c|c|c|c|c|c|c|c|c|}
\hline \multirow[b]{2}{*}{ Days* } & \multicolumn{2}{|c|}{ Cow 119} & \multicolumn{2}{|c|}{ Cow 120} & \multicolumn{2}{|c|}{ Cow 108} & \multicolumn{2}{|c|}{ Cow 132} & \multicolumn{2}{|c|}{ Cow 149} & \multicolumn{2}{|c|}{ Cow 163} \\
\hline & L & $\mathbf{R}$ & $\mathbf{L}$ & $\mathbf{R}$ & $\mathbf{L}$ & $\mathbf{R}$ & L & $\mathbf{R}$ & $\mathbf{R}$ & $\mathrm{L}$ & $\mathbf{R}$ & $\mathbf{L}$ \\
\hline-40 to -35 & Fs & Fs & Fs & Fs & Fs & Fs & Fs & & $-\dagger$ & $-\dagger$ & -+ & -+ \\
\hline-35 to -30 & & & Fm & & & & & & $-\dagger$ & $-\dagger$ & $-\dagger$ & -+ \\
\hline-30 to -25 & Fm & & & & Fs & $\mathrm{Fm}$ & & $\mathrm{Fm}$ & $\mathrm{Fm}$ & & & \\
\hline-25 to -20 & & & Fm & & $\cdot$ & Fl & & & $\mathrm{Fm}$ & & Fvl & \\
\hline-20 to -15 & & & & $\mathrm{Fm}$ & & Fm & & & & & $\mathrm{F} 1$ & \\
\hline-15 to -10 & & $\mathrm{Fl}$ & & Fm & Fvl & Fvl & & & Fvl & & & \\
\hline-10 to -4 & & & & Fvl & Fvl & Fm & $\mathrm{Fm}$ & $\mathrm{Fm}$ & $\mathrm{Fm}$ & & Fvl & Fl \\
\hline-5 to 0 & $\mathrm{Fm}$ & & $\mathrm{Fm} \S$ & & Fs & $\mathrm{Fl}$ & & Fl & Fvl & & Fl & \\
\hline 0 to +5 & Fs & Fs & CLm & & $\S$ & $\mathbf{F l}$ & & $\mathrm{Fl}$ & Fvl§ & & $\mathrm{Fm}$ & Fm \\
\hline+5 to 10 & Fs§ & Fl & CLm & & $\mathbf{F l}$ & & $\mathrm{Fl}$ & & CLs & & $\S$ & \\
\hline+10 to +15 & & $\mathrm{CLl}$ & $\mathrm{CL}$ & & -+ & $-\dagger$ & $-\dagger$ & $-\dagger$ & CLvl & & CLm & $\mathrm{Fl}$ \\
\hline
\end{tabular}

$\mathrm{CL}=$ corpus luteum; $\mathrm{F}=$ follicle; $\mathrm{s} ₹ 0.2 \mathrm{~cm}, \mathrm{~m} \gtrless 0.6 \mathrm{~cm}, 1 \gtrless 1.0 \mathrm{~cm}, \mathrm{vl} \gtrless 2.0 \mathrm{~cm}$ diameter.

* Day $0=2$ nd day of first 3 days of progesterone $>0.5 \mathrm{ng} / \mathrm{ml}$.

$\dagger$ Not palpated.

$\S$ Time of first oestrus. 
Table 3. The number and height of peaks of LH during periods of intensive bleeding occurring during the periods indicated for 5 cows returning to oestrus after parturition

\begin{tabular}{ccccccc}
\hline & $\begin{array}{c}\text { Days } \\
-53 \text { to }-49\end{array}$ & $\begin{array}{c}\text { Days } \\
-43 \text { to }-38\end{array}$ & $\begin{array}{c}\text { Days } \\
-33 \text { to }-28\end{array}$ & $\begin{array}{c}\text { Days } \\
-23 \text { to }-18\end{array}$ & $\begin{array}{c}\text { Days } \\
-12 \text { to }-7\end{array}$ & $\begin{array}{c}\text { Days } \\
-3 \text { to } 2\end{array}$ \\
\hline $\begin{array}{c}\text { Peak height } \\
\text { (ng/ml) }\end{array}$ & $3.0 \pm 0.44$ & $3.8 \pm 0.58$ & $6.2 \pm 0.60^{*} \dagger$ & $6.8 \pm 0.61$ & $6.1 \pm 0.78$ & $2.3 \pm 0.17^{*}$ \\
No. of peaks & $4.5 \pm 1.19$ & $5.8 \pm 1.00$ & $9.2 \pm 0.37^{*}$ & $7.2 \pm 0.80$ & $8.2 \pm 1.02$ & $8.8 \pm 1.75$ \\
\hline
\end{tabular}

Day $0=2 \mathrm{nd}$ day of first 3 days when progesterone $>0.5 \mathrm{ng} / \mathrm{ml}$.

* Significantly different from the previous observation.

$\dagger$ Significantly different from the value at Days -53 to -49 .

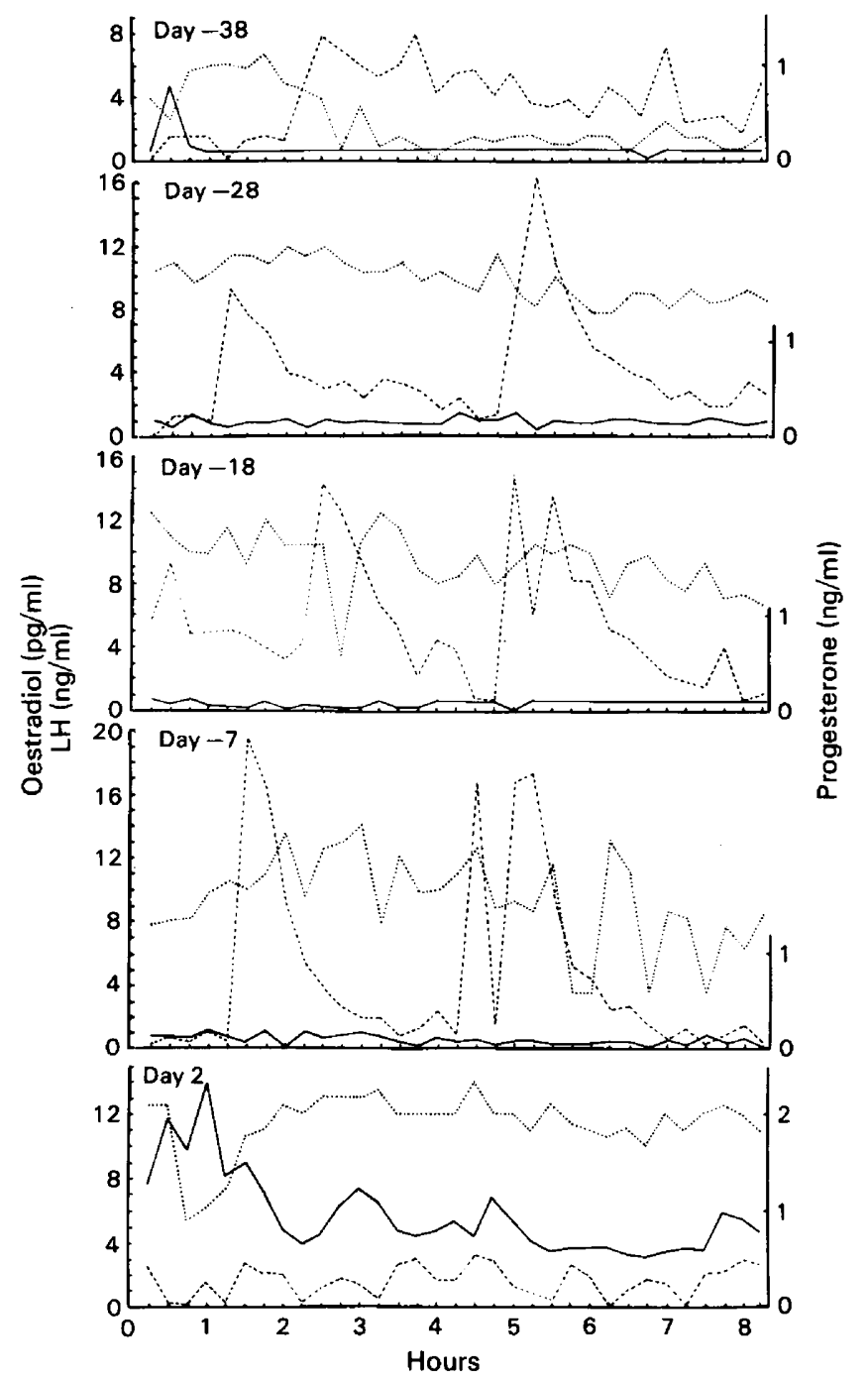

Text-6g. 2. Peripheral plasma concentrations of LH (---), oestradiol-17 $\beta(\cdots)$ and progesterone ( $\longrightarrow$ ) for one representative cow (No. 149) bled every $15 \mathrm{~min}$ for $8 \mathrm{~h}$ on the days indicated. Day 0 is the 2 nd day of the first rise in plasma progesterone by $>0.5 \mathrm{ng} / \mathrm{ml}$. 
and $429 \pm 21 \mathrm{~kg}$ at $32-49$ days after calving. Five cows were detected in oestrus, with an average post-partum interval to first oestrus of $59.8 \pm 3.7$ days. Cow 132 lost her Kamar detector just before an apparent oestrus and Cow 134 was not detected in oestrus by 77 days post partum. The concentrations of LH, progesterone and oestradiol-17 $\beta$ for 6 of the cows are shown in Text-fig. 1. In the 6 cows that returned to oestrus, plasma concentrations of progesterone were low until $55.5 \pm 3.0$ days post partum, rose to exceed $0.5 \mathrm{ng} / \mathrm{ml} \mathrm{plasma} \mathrm{for}$ $4.0 \pm 0.4$ days, declined for $5.0 \pm 0.5$ days and rose again to normal luteal-phase levels. Progesterone levels remained low in Cow 134, that failed to return to oestrus. In the 5 cows in which the time of first oestrus was accurately determined, the initial elevation in plasma concentration of progesterone preceded first oestrus in 4 and followed it in 1 . As the initial increase in plasma concentration of progesterone was such a consistent finding, and as the concomitant return to reproductive cyclicity was the event of primary interest, the data in Text-fig. 1 have been centered (Day 0 ) around the second consecutive day of the first period in which plasma concentrations of progesterone exceeded $0.5 \mathrm{ng} / \mathrm{ml}$ for at least 3 days.

Plasma concentrations of oestradiol-17 $\beta$ declined after parturition and were subsequently quite variable in all cows studied, no apparent trend could be detected. Plasma concentrations of LH changed significantly during the period of the study $(P<0.005)$ and an episodic mode of secretion seemed likely. Taking the average values over periods of 10 days for the 6 cows that returned to oestrus, the pattern shown in Table 1 emerged.

Table 2 shows the ovarian structures palpable per rectum for the 6 cows that returned to oestrus during the study. Although variable, the data indicated an increased production of medium-sized and large follicles as the first oestrus and return to reproductive cyclicity approached. No correlation of follicular patterns and the concentration of oestradiol-17 $\beta$ in plasma was apparent. No corpora lutea were detected with any assurance until after first oestrus, when plasma concentrations of progesterone rose to normal luteal phase levels. However, prior to first oestrus and during the first phase of elevated plasma concentrations of progesterone, the presence of an early corpus luteum was suspected in Cows 108, 149 and 163.

Of the 6 cows that were bled intensively every 10 days post partum, Cows 108, 119, 120, 132 and 149 returned to oestrus during the study: the results for Cow 149 are shown in Text-fig. 2 as representative. Plasma concentrations of progesterone were low and stable during all periods of intensive blood sampling, except those that coincided with the periods of elevated plasma concentrations of progesterone described in Text-fig. 1. Plasma concentrations of oestradiol-17 $\beta$ were quite variable within and between the periods of intensive bleeding, but no significant trend could be detected. The pattern of plasma concentrations of LH suggested an episodic mode of secretion (Table 3).

\section{Discussion}

The decline in plasma concentrations of oestradiol-17 $\beta$ following parturition and the subsequent levels of oestradiol-17 $\beta$ resemble previous observations (Henricks, Dickey, Hill \& Johnston, 1972; Hoffmann et al., 1973; Smith et al., 1973; Arije et al., 1974; Corah et al., 1974). The variability of plasma concentrations of oestradiol-17 $\beta$ in samples taken daily and more intensively may well be due to the increasing, but variable, follicular growth observed post partum. However, no significant relationship emerged between the pattern of palpable ovarian follicles and plasma concentrations of oestradiol-17ß. A variable pattern of follicular growth and atresia (Morrow et al., 1969) and plasma concentrations of oestradiol (Echternkamp \& Hansel, 1973) have been previously reported in the post-partum cow. As has been previously reported (Donaldson et al., 1970; Arije et al., 1974; Corah et al., 1974; Lamming \& Bulman, 1976; Webb et al., 1977; Schams et al., 1978), plasma concentrations of progesterone were low after parturition, but the transient rise in progesterone concentration that has been ${ }^{2}$ previousis 
suggested to occur before the first normal luteal phase was very clearly confirmed in the present study. All 6 of our cows returning to oestrus exhibited this early elevation of plasma progesterone and oestrus followed it in 4 of 5 cows. The consistency of this elevation of progesterone in terms of length, magnitude and occurrence with respect to first oestrus and the first normal luteal phase is striking. Palpation of the ovaries did not clearly indicate the occurrence of ovulation and the formation of a corpus luteum until the time that plasma progesterone levels resembled those of a normal luteal phase. There were apparently many large follicles present at the time of the early elevation of progesterone and it is possible that luteinized follicles (Corah et al., 1974) were the source of progesterone, or that ovulation took place and that an abnormal, short-lived and sub-functional corpus luteum developed.

Plasma LH concentrations clearly increased over the post-partum period and although some variability in pattern was observed the increase was due to a modulation of the number and magnitude of the LH peaks. Maximum magnitude and frequency of LH peaks occurred about 33-10 days before the initial elevation of plasma progesterone, i.e. when there was a marked development of large follicles and large variations of oestradiol-17 $\beta$. During the period from the early progesterone elevation through first oestrus and the onset of the first normal luteal phase, the average peak concentrations of LH in plasma tended to decline. In the dairy cow and the suckling beef cow an increase in episodic secretion of $\mathbf{L H}$ before first ovulation has been reported (Arije et al., 1974; Stevenson \& Britt, 1979), but is not consistently noted (Schams et al., 1978). Pituitary LH stores appear to increase post partum (Saiduddin et al., 1968) and FSH stores decline (Labhsetwar et al., 1964). In dairy cattle plasma FSH concentrations have been reported to rise initially post partum, declining to first oestrus (Dobson, 1978), or to exhibit no change (Schams et al., 1978). If an extrapolation from the dairy cow to the longer post-partum period of the suckling beef cow can be made, it would appear that plasma FSH concentrations may behave in a similar pattern to those of LH observed in the present study (Dobson, 1978). It is apparent that lactation, and especially suckling with lactation, prolong post-partum anoestrus (Short et al., 1972). In the rat lactation suppresses LH and FSH secretion (Smith \& Neill, 1977). Therefore, following parturition and under the suppressive effect of lactation, gonadotrophin secretion appears to recover gradually in suckling beef cows, culminating in the luteinization of large ovarian follicles, or possibly in ovulation and the formation of subnormal, short-lived corpora lutea.

The exact endocrine mechanisms that are needed to permit ovulation are unclear. After the initial rise in plasma progesterone and with the recurrence of cyclicity in the suckling beef cow, plasma LH concentrations appear to decline and resemble more closely the basal values of the cyclic cow (Henricks, Dickey \& Niswender, 1970). Plasma concentrations of oestradiol-17 $\beta$ do not clearly change at this time, indicating that progesterone may have an organizing effect on gonadotrophin secretion, as it appears to do in the cyclic ewe (Hauger, Karsch \& Foster, 1977), and may also be necessary to programme the resumption of behavioural oestrus (Lindsay, 1966). In the ewe, changes in the negative feedback effects of oestradiol-17 $\beta$ on LH secretion may be important in controlling the seasonality of breeding activity. However, in the lactating post-partum ewe changes in this interaction are not observed (Legan, Karsch \& Foster, 1977; Foster, 1979). In cattle, the source of the early elevation of plasma concentrations of progesterone is unclear, and the exact mechanism that stimulates and controls the duration of its secretion is also unknown. This transient rise in plasma progesterone concentration may be critical in reorganizing the ovarian-pituitary-hypothalamic axis after parturition (Webb et al., 1977).

We thank Mr D. Rieger, and Dr B. Murphy for help in collecting blood samples; Dr G. D. Niswender for the ovine LH antiserum (GND-15); Dr H. Dobson for the progesterone antiserum (HD-RC-4/10/73); NIAMDD for NIH-LH-B7; and Dr L. E. Reichert for the highly purified bovine LH (LER-1716-2). The work was supported by grants from the Alberta Agricultural Research Trust and the National Research Council. Bioscientifica.com at 04/26/2023 09:15:28AM 


\section{References}

Arije, G.R., Wiltbank, J.N. \& Hopwood, M.L. (1974) Hormone levels in pre- and post-parturient beef cows. J. Anim. Sci. 39, 228-247.

Corah, L.R., Quealy, A.P., Dunn, T.G. \& Kaltenbach, C.C. (1974) Prepartum and post partum levels of progesterone and estradiol in beef heifers fed two levels of energy. J. Anim. Sci. 39, 380-385.

Dobson, H. (1978) Radioimmunoassay of FSH in the plasma of post-partum dairy cows. J. Reprod. Fert. $52,45-49$.

Donaldson, L.E., Bassett, J.M. \& Thorburn, G.D. (1970) Peripheral plasma progesterone concentrations of cows during puberty, oestrous cycles, pregnancy and lactation, and the effects of undernutrition or exogenous oxytocin on progesterone concentrations. J. Endocr. 48, 599-614.

Echternkamp, S.E. \& Hansel, W. (1973) Concurrent changes in bovine plasma hormone levels prior to and during the first post partum estrous cycle. $J$. Anim. Sci. 37, 1362-1370.

Foster, D.L. (1979) Is the mechanism for resumption of ovulation following parturition in the sheep similar to that for onset of puberty or onset of the adult breeding season? Biol. Reprod. 20 (Suppl. No. 1), $25 \mathrm{~A}, \mathrm{Abstr}$.

Greenwood, F.C., Hunter, W.M. \& Glover, J.S. (1963) The preparation of ${ }^{131}$ I-labelled human growth hormone of high specific radioactivity. Biochem. J. 89, 114-123.

Hauger, R.L., Karsch, F.J. \& Foster, D.L. (1977) A new concept for control of the estrous cycle of the ewe based on the temporal relationship between luteinising hormone, estradiol and progesterone in peripheral serum and evidence that progesterone inhibits tonic LH secretion. Endocrinology 101, 807-817.

Henricks, D.M., Dickey, J.F. \& Niswender, G.D. (1970) Serum luteinising hormone and plasma progesterone levels during the estrous cycle and early pregnancy in cows. Biol. Reprod. 2, 346-351.

Henricks, D.M., Dickey, J.F., Hill, J.R. \& Johnston, W.E. (1972) Plasma estrogen and progesterone levels after mating and during late pregnancy and post partum cows. Endocrinology 90, 1336-1342.

Hoffmann, B., Schams, D., Gimenez, T., Ender, M.L., Herrmann, C.L. \& Karg, H. (1973) Changes of progesterone, total oestrogens, corticosteroids, prolactin and LH in bovine peripheral plasma around parturition with special reference to the effect of exogenous corticoids and a prolactin inhibitor respectively. Acta endocr., Copenh. 73, 385-395.

Labhsetwar, A.P., Collins, W.E., Tyler, W.J. \& Casida, L.E. (1964) Some pituitary-ovarian relationships in the periparturient cow. J. Reprod. Fert. 8, 85-90.

Lamming, G.E. \& Bulman, D.C. (1976) the use of milk progesterone radioimmunoassay in the diagnosis and treatment of subfertility in dairy cows. Br. vet. J. 132, 507-517.

Legan, S.J., Karsch, F.J. \& Foster, D.L. (1977) The endocrine control of seasonal reproductive function in the ewe: a marked change in response to the negative feedback action of estradiol on luteinising hormone secretion. Endocrinology 101, 818-824.

Lindsay, D.R. (1966) Moderation of behavioural oestrus in the ewe by social and hormonal factors. Anim. Behav. 14, 73-83.

Morrow, D.A., Roberts, S.J. \& McEntee, K. (1969) Review of post partum ovarian activity and involution of the uterus and cervix in cattle. Cornell Vet. 59, 134-154.

Niswender, G.D., Reichert, L.E., Jr, Midgley, A.R. \& Nalbandov, A.V. (1969) Radioimmunoassay for bovine and ovine luteinizing hormone. Endocrinology 84, 1166-1173.

Pope, G.S., Gupta, S.K. \& Munro, I.B. (1969) Progesterone levels in the systemic plasma of pregnant, cycling and ovariectomised cows. J. Reprod. Fert. 20, 369-381.

Rawlings, N.C., Kennedy, S.W., Chang, C.H., Hill, J.R., Jr, \& Henricks, D.M. (1977) Onset of seasonal anestrus in the ewe. J. Anim. Sci. 44, 791-797.

Saiduddin, S., Riesen, J.W., Tyler, W.J. \& Casida, L.E. (1968) Relations of postpartum interval to pituitary gonadotrophins, ovarian follicular development and fertility in dairy cows. Wisconsin Res. Bull. 270, $15-22$.

Schams, D., Schallenberger, E., Menzer, C.H., Stangl, J., Zottmeier, K., Hoffmann, B. \& Karg, H. (1978) Profiles of LH, FSH and progesterone in postpartum dairy cows and their relationship to the commencement of cyclic functions. Theriogenology 10, 352-468.

Short, R.E., Bellows, R.A., Moody, E.L. \& Howland, B.E. (1972) Effects of suckling and mastectomy on bovine post partum reproduction. J. Anim. Sci. 34, 70-74.

Smith, M.S. \& Neill, J.D. (1977) Inhibition of gonadotropin secretion during lactation in the rat: relative contributions of suckling and ovarian steroids. Biol. Reprod. 17, 255-261.

Smith, V.G., Edgerton, L.A., Hafs, H.D. \& Convey, E.M. (1973) Bovine serum estrogens, progestins and glucocorticoids during late pregnancy, parturition, and early lactation. J. Anim. Sci. 36, 391-396.

Steele, R.G.D. \& Torrie, J.H. (1960) Principles and Procedures of Statistics. McGraw-Hill, New York.

Stevenson, J.S. \& Britt, J.H. (1979) Relationships among luteinising hormone, estradiol, progesterone, glucocorticoids, milk yield, body weight and post partum ovarian activity in holstein cows. J. Anim. Sci. 48, 570-577.

Wagner, W.C. \& Hansel, W. (1969) Reproductive physiology of the post partum cow. I. Clinical and histological findings. J. Reprod. Fert. 18, 493-500.

Wagner, W.C. \& Oxenreider, S.L. (1971) Endocrine physiology following parturition. J. Anim. Sci. 32, (Suppl. 1), 1-16.

Webb, R., Lamming, G.E., Haynes, N.B., Hafs, H.D. \& Manns, J.G. (1977) Response of cyclic and postpartum suckled cows to injections of synthetic LH-RH. J. Reprod. Fert. 50, 203-210. 